\title{
A Reflection on 'Independence and the Creation of Nation-States in Iberian America'
}

\section{MALCOLM McKINNON}

Marco A. Pamplona's paper reminds the New Zealand reader that the category 'Latin America' embraces many very different nation-making histories which touch only at points on New Zealand's own nation-making experience. In his wide-ranging and thoughtful paper Pamplona is concerned in particular to explain the contrast between Spanish America - what became the chain of independent states from Mexico to Chile and Argentina - and Portuguese America - what became Brazil.

Spanish and Portuguese independence movements arose in the aftermath of the French Revolution and Napoleon's invasion of the Iberian Peninsula (Spain and Portugal). For the Spanish colonies in the Americas, Napoleon's invasion meant the obliteration, even if temporarily, of metropolitan power. For Portuguese America, to which the Portuguese court and other institutions of government migrated, it represented an enhancement of that power. In that contrast, as much as any, can be discerned an explanation of Spanish America's division and of Brazilian unity. Further, within Spanish America each of the ultimately 17 successor states had a different evolution. For some of those states, independence arose from a struggle against the returning Spanish; for others it was a struggle against their own neighbours.

In 1822 Portuguese reformers forced the return of the monarchy to Portugal at which time the most influential elites in Brazil set up Brazil's own monarchy, which stamped its authority on the whole of the former Portuguese territories.

Pamplona's account makes clear the contingent quality of these different outcomes. The early history of independent Brazil is replete with secessionist movements, from both 'right' and 'left' which could in any instance have led to independence and indeed in one instance - Uruguay - did. Conversely some of the larger post-independence entities in Spanish America - Central America (which broke into five separate states) and New Granada (which broke into three) might have survived intact.

Pamplona's stress on the variability of the process of state- and nationformation, both between Spanish and Portuguese America, and within the two entities, holds true a fortiori when New Zealand is brought into the 
equation. Some of the indications of why this might be the case are touched on in the earlier part of Pamplona's discussion, when he compares the United States and Latin America.

Pamplona notes that United States independence 'responded to a very specific conjuncture of late eighteenth-century British politics, in the aftermath of the Seven Year War' (1756-1763), in which Britain defeated France, thereby removing some of external constraint on its American colonies, whilst also driving them towards a collision with the metropolis, as the latter loaded some of the costs of the war on the colonies. Those colonies, unlike the colonies of Spain and Portugal, already had representative institutions, not to mention a highly developed civil society independent of state, established churches and military alike.

For New Zealand the contrasts with Latin America are even greater. At the opening of the nineteenth century the greater part of the Americas had been under Spanish or Portuguese rule for at least 250 years. At that same time, New Zealand, along with Australia and the island groups of the South-west Pacific, had only just been brought within the ambit of European contact. The 100,000 or so New Zealanders - the Māori - lived by gardening, food gathering, bird hunting and fishing, used stone tools and had a rich oral, but no written culture.

Like the colonials in many parts of Latin America, white settlers in New Zealand had to deal with 'Indios' - as indeed Māori were initially called by James Cook and other eighteenth-century explorers. But the encounter was not as catastrophic as the equivalent sixteenth- and seventeenth-century histories in Mexico and Peru, where large indigenous populations were forcibly incorporated into the colonial state as unwaged labour. Nor was a failure to exploit native labour compensated for, as in Brazil, with slaves brought in the first instance from Africa.

From this Māori perspective, the analogue in the Americas of the New Zealand experience was not the independence struggles of the Spanish American states and Brazil, but the expansion of Brazil and other states into the South American interior, something Pamplona touches on in comments on Brazil during the imperial era up to 1889. An even closer parallel would be the expansion of Argentina and in particular Chile southward towards the bottom of the continent. All of these areas were populated by indigenous peoples whose society and culture had many parallels to that of Māori and who, like Māori, both engaged with and fought against the newcomers.

Turn from Māori to the settlers whose arrival contributed to the establishment of a British colony in New Zealand in 1840, and other differences are found. These settlers were the equivalent of Spanish America's 'peninsulares' - migrants from Spain seeking to make new lives and hopefully fortunes in the Americas. But the recruits to 1840s New 
Zealand were more like their North American than their South American peers - more literate, not tied to an established church, and with a propensity for commerce and civil society.

The most dramatic contrast with Latin America lay in the speed with which the New Zealand colonists gained autonomous institutions. From the first arrival of organized groups of settlers in 1840 to the establishment of a constitutional government took just 13 years. There was no fighting, no war for independence, but a swift (if still not swift enough for some of the colonists) transfer of power from metropolis to colony. Initially relations with Māori were exempted from settler control but in 1864 the colonial government acquired that power as well and from then on was in complete command of the domestic affairs of the colony - the only ones that mattered to most of its inhabitants. Thus New Zealand, though formally still a colony, compressed into a dozen years a process which in the Americas had taken by some measures roughly 12 times as long as that.

Why the speed? The simple - and still compelling - answer is that Britain, in turning decisively, as it did in the nineteenth century, towards a political economy of free trade, lost interest in ruling colonies, given that it no longer wished to direct their trade or their finances. This had not been the case in 1776, when the American colonies had rebelled; that it was the case in the 1840s and 1850s owed something to the outcome of that rebellion, but more to the immensely greater influence of British commerce, and the global reach of its interests, by the latter date. It was that same influence which had 'opened' Latin America to traders of all nations earlier in the century.

Scroll forward another generation - to around 1890 - and New Zealand, though still formally a 'colony', was more developed than any state in Latin America in terms of infrastructure, life expectancy, education and even the rights of indigenous people. The six provinces established in 1853, acknowledgement of the number of distinct settlements, had not split apart but had been welded into one - a comment on the integration that came with development if also on New Zealand being Ecuador- not Brazil-sized. As for larger entities, New Zealand did not have to 'leave' the Australian federation set up in 1901; it simply decided not to join it.

It was left to the twentieth century, and in particular the experience shared by New Zealand and southern South America of deepening economic ties with Britain at the outset of the century; the economic turmoil of the 1930s; and the modernization of many Latin American states in the mid to late twentieth century - as urbanization, literacy, democracy, the rule of law and women's and indigenous rights acquired substance as well as form - to bring parallels rather than contrasts between New Zealand and its 'distant neighbours' to the fore. 
Journal of New Zealand Studies 